\title{
XXXV. THE BIOCHEMISTRY OF ALUMINIUM.
}

\section{EXCRETION AND ABSORPTION OF ALUMINIUM IN THE RAT.}

\author{
BY KENNETH MACKENZIE. \\ From the Rowett Research Institute, Aberdeen.
}

(Received January 7th, 1931.)

IT has previously been shown by balance experiments with pigs that practically the whole of the aluminium provided as a supplement to the diet is voided in the faeces [Mackenzie, 1930]. With such animals there is a difficulty in devising a ration free from aluminium and accordingly this work has been supplemented by experiments with rats, where the ration could be built up by the use of highly purified foodstuffs.

The experiments of Flinn and Inouye [1928] on the excretion of aluminium by rats led them to believe that, when an aluminium salt was administered in the drinking water, $30 \%$ of the aluminium was excreted in the urine and $70 \%$ in the faeces. As details of the procedure are not given, it is uncertain whether contamination of urine by the faeces was prevented, and whether the drinking water was guarded against mechanical dissipation. The absorption of aluminium by rats, fed on diets containing aluminium over considerable periods, has been reported upon by Myers and Mull [1928]. There appeared to be some increase in the aluminium content of the tissues, though the method of analysis was not sensitive enough to give definite results. Wu [1929] states that rats fed on aluminised diets show an increased content of aluminium in the liver as compared with normal rats $(0.97 \mathrm{mg}$. per $100 \mathrm{~g}$. as compared with $0.59 \mathrm{mg}$. per $100 \mathrm{~g}$.). References to experiments with other species were given in the previous publication [Mackenzie, 1930].

\section{EXPERIMENTAL.}

The chief difficulty in these experiments was to separate the three materials likely to contain aluminium, namely, the food, the urine and the faeces, as thoroughly as possible, while not interfering with the regular life of the animals. After a few trials the following method was adopted as the simplest and most satisfactory. The rats were kept in individual glass jars (15" long, $11^{\prime \prime}$ wide, $5^{\prime \prime}$ high) with a glass plate closing the mouth (fixed in position by wire), but leaving a gap of $\frac{1}{2}$ " at each side for air circulation. After preliminary cleaning the base of the jar was covered with a pad of filter-paper, made by folding a large sheet $\left(40^{\prime \prime} \times 30^{\prime \prime}\right)$ into two or three layers of suitable shape, 
on which was superimposed a fine iron wire gauze mat mounted on a stout wire frame which fitted the bottom of the jar accurately. The food container was of special construction designed to prevent scattering of food; its dimensions and a section are given in Fig. 1. The lid was held in position by bayonet catches, and through the hole in its centre the rat could remove food by the mouth, but owing to the sloping guard ring was unable to drag it out with its paws. Water was supplied from drop-bottles, wired into position in the apertures at each side of the cage. The cages were cleaned

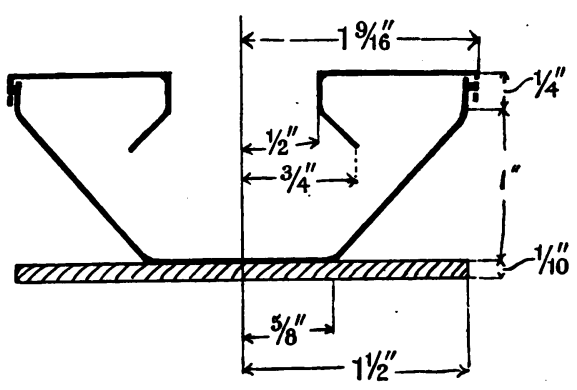

Fig. 1. Diagram of food trough. Body of 12-gauge zinc sheet. Base of hard lead sheet. out daily, the rat being removed to another cage; the faeces were brushed into a wide-mouth bottle and the gauze mat was taken out and shaken to remove any small particles of food, which were collected and returned to the food trough.

The rats used in these experiments were members of larger groups of 30-40 animals which were employed on feeding and fertility tests; these groups of rats were chosen from a number of young albino or Norwegian rats recently weaned, which were divided into two symmetrical groups, one receiving a synthetic diet approximately free from aluminium and adequate for growth, the other a similar diet with the addition of $0.1 \%$ aluminium. Growth was usually regular, the animals gaining in weight steadily from $40 \mathrm{~g}$. to $200 \mathrm{~g}$. in the course of 12-16 weeks. In the first two metabolic experiments, fullygrown animals were used, three animals on the control, and three on the aluminised diet, and each animal occupied a separate cage. In the third experiment, animals 12 weeks old, averaging $120 \mathrm{~g}$. in weight were employed, and the three animals of each group were placed in the same cage. It was hoped by this means to reduce the amount of aluminium which could not be accounted for, but the improvement in the result was not noticeable.

\section{Analysis of material.}

The food. Sufficient amounts of the control diet and aluminised diet were removed from the main bulk of the stock rations, well mixed, and sampled. The control diet was analysed by the spectrographic method (a modified version of the method used by McCollum, Rask and Becker [1928]) and the aluminised diet by the method of Schmidt and Hoagland [1912].

The faeces. These were collected daily during the metabolic period and at its conclusion were dried, ground and analysed, the control group by the colorimetric method [Myers and Morrison, 1928], the aluminised group by the gravimetric method.

The urine. The filter papers were removed from the cages, dried, brushed 
lightly to remove any traces of adherent food, ashed, and analysed by the colorimetric method. Blank determinations were made on a few fresh filter papers.

Table I. Diets.

Yeast

Caseinogen

Salt mixture 185

Cellulose

Butter

Starch

A.P.B.P.*

Al. content mg./100 g.

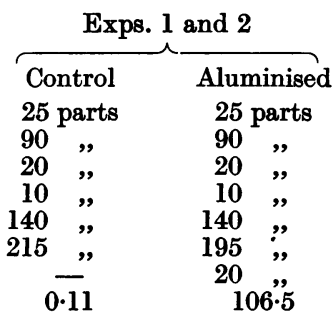

\begin{tabular}{|c|c|}
\hline \multicolumn{2}{|c|}{ Exp. 3} \\
\hline Control & Aluminised \\
\hline 24 parts & 24 parts \\
\hline 88, & $88^{\prime \prime}$ \\
\hline 20 & 20 \\
\hline $10 \quad$ & 10 \\
\hline 80 & 80 \\
\hline 215, & 200 \\
\hline- & 15 \\
\hline $0 \cdot 11$ & $85 \cdot 4$ \\
\hline
\end{tabular}

* This represents a commercial brand of baking powder, containing acid calcium phosphate and sodium aluminium sulphate; it was decomposed with water and dried, the product containing about $3 \%$ of aluminium.

Table II. Results of experiments carried out on groups of three rats.

\begin{tabular}{|c|c|c|c|c|c|c|}
\hline \multirow{3}{*}{$\begin{array}{l}\text { Food eaten (g.) } \\
\text { Duration (days) } \\
\text { Food eaten per rat daily }\end{array}$} & \multicolumn{2}{|c|}{ Exp. 1} & \multicolumn{2}{|c|}{ Exp. 2} & \multicolumn{2}{|c|}{ Exp. 3} \\
\hline & Control & Aluminium & Control & Aluminium & Control & Aluminium \\
\hline & $\begin{array}{r}540 \\
12 \\
15\end{array}$ & $\begin{array}{r}540 \\
12 \\
15\end{array}$ & $\begin{array}{c}362 \\
7 \\
17 \cdot 2\end{array}$ & $\begin{array}{c}393 \\
7 \\
18 \cdot 7\end{array}$ & $\begin{array}{c}356 \\
9 \\
13 \cdot 2\end{array}$ & $\begin{array}{c}321 \\
9 \\
11.9\end{array}$ \\
\hline $\begin{array}{l}\text { Total aluminium ingested } \\
\text { (mg.) }\end{array}$ & $0 \cdot 59$ & $575 \cdot 0$ & $0 \cdot 395$ & $418 \cdot 5$ & $0 \cdot 39$ & $274 \cdot 1$ \\
\hline $\begin{array}{l}\text { Aluminium output (mg.): } \\
(a) \text { in urine } \\
(b) \text { in faeces }\end{array}$ & $\begin{array}{l}0 \cdot 006^{*} \\
0.47\end{array}$ & $\begin{array}{l}0 \cdot 026^{*} \\
484 \cdot 2\end{array}$ & $\begin{array}{l}0 \cdot 006^{*} \\
0 \cdot 29\end{array}$ & $\begin{array}{l}0 \cdot 014^{*} \\
394 \cdot 1\end{array}$ & $\begin{array}{l}0.008 \\
0.44\end{array}$ & $\begin{array}{l}0 \cdot 024 \\
261 \cdot 3\end{array}$ \\
\hline $\begin{array}{l}\text { Total aluminium output } \\
\text { (mg.) }\end{array}$ & $0 \cdot 476$ & $484 \cdot 2$ & $0 \cdot 296$ & $394 \cdot 1$ & $0 \cdot 44 \varepsilon$ & $261 \cdot 3$ \\
\hline Output as $\%$ ingestion & $80 \cdot 7$ & $\mathbf{8 4} \cdot 2$ & $74 \cdot 9$ & $94 \cdot 2$ & $114 \cdot 9$ & $95 \cdot 4$ \\
\hline
\end{tabular}

Urinary excretion. In arriving at the figure for urinary excretion it is necessary to take into account the value of the blank as determined on several fresh sheets of filter-paper. The average of six blanks was $0.003 \mathrm{mg}$., and the largest single figure obtained was $0.008 \mathrm{mg}$. Since the analytical method employed is of doubtful accuracy with amounts of aluminium less than $0.005 \mathrm{mg}$., only two of the results for urinary excretion can be accepted as definitely indicating the presence of aluminium - the "aluminium groups" of Exps. 1 and 3. In these cases, it is possible that a small amount of the food employed in the experiment may have passed through the gauze mat and become incorporated in the paper when analysed; an amount of $20 \mathrm{mg}$. so included would be sufficient to account for the amount of aluminium observed. But even if this is not so, the amount of aluminium is so small in relation to the total ingestion as to make it of little significance.

The faeces. (a) Recovery of aluminium ingested by control animals. The disparity in the figures of intake and output is probably due to analytical error. The amount of aluminium is in all cases very small, and the systematic error 
is consequently much greater than usual. Combination of all the results for the control animals gives an average recovery of $90 \cdot 2 \%$, or an average possible absorption of $0.04 \mathrm{mg}$. per rat.

(b) Recovery of aluminium ingested by aluminium-fed animals. In the second and third experiments a high level of recovery, approximately $95 \%$, was obtained, but the recovery in the first experiment was unexpectedly low. This was assumed to be due to coprophagy, though this had not been observed during the experiment; it may have occurred, since the rats were supplied with a fixed amount of food daily, and it is possible that this was not sufficient in the case of one or two rats. In the subsequent experiments, an excess of food was always supplied, and only the total weight eaten for the whole period was ascertained. The recovery of aluminium was approximately equal in the two latter cases, and it seems doubtful whether attention to detail could reduce the unavoidable loss much further. Two causes may operate to cause error: mechanical losses, and variation in the rate at which the animals consume their food. It seems unlikely that the latter can be a serious source of error. The use of three animals over a period of 7 days would reduce such variation to a very small percentage of the total.

\section{Possible absorption of aluminium as determined by analyses of the animal organs.}

In the course of the feeding and rearing experiments with which the above metabolic experiments were connected, a number of the adult rats were killed and their internal organs were analysed for aluminium. The results were considered applicable to the problem immediately under consideration, as these rats received exactly the same food and treatment throughout their life-period. The analyses were conducted on the organs removed from 8-10 rats, so as to minimise systematic errors, experience having shown that with the smaller amount obtained from 3 rats these were apt to be unduly large.

The analytical data for two groups of rats are given in Table III. Series A contained the rats used in Exps. 1 and 2. Series B contained the animals used in Exp. 3. All rats were full-grown and healthy, with an average weight in excess of $200 \mathrm{~g}$.

\begin{tabular}{|c|c|c|c|c|c|c|}
\hline \multirow[b]{2}{*}{ Series A: } & \multirow[b]{2}{*}{$\begin{array}{l}\text { No. of rats } \\
\text { examined }\end{array}$} & \multicolumn{5}{|c|}{ Aluminium found in mg./100 g. fresh material } \\
\hline & & Liver & Lung & Heart & Stomach & $\underset{\text { intestine }}{\text { Small }}$ \\
\hline $\begin{array}{l}\text { Control diet } \\
\text { Aluminium diet }\end{array}$ & $\begin{array}{r}10 \\
8\end{array}$ & $\begin{array}{l}1 \cdot 8 \\
2 \cdot 2\end{array}$ & $\begin{array}{l}0.32 \\
0 \cdot 22\end{array}$ & - & $\begin{array}{l}3 \cdot 8 \\
1 \cdot 1\end{array}$ & $\begin{array}{l}2 \cdot 8 \\
2 \cdot 9\end{array}$ \\
\hline $\begin{array}{l}\text { Series B: } \\
\text { Control diet } \\
\text { Aluminium diet }\end{array}$ & $\begin{array}{l}9 \\
8\end{array}$ & $\begin{array}{l}1 \cdot 6 \\
1 \cdot 2\end{array}$ & $\begin{array}{l}0 \cdot 16 \\
0 \cdot 14\end{array}$ & $\begin{array}{l}0.20 \\
0.24\end{array}$ & $\begin{array}{l}\mathbf{1} \cdot 35 \\
\mathbf{2} \cdot 6\end{array}$ & $\begin{array}{l}1 \cdot 15 \\
2 \cdot 2\end{array}$ \\
\hline
\end{tabular}

These results cannot be considered as evidence that absorption of aluminium occurs through ingestion of aluminised food; the variations between the 
different groups are not greater than have been obtained in other series of analyses in which no aluminium was fed. The general trend of these experiments is to show that aluminium plays no important part in the metabolism of the rat, and supports the theory that aluminium, when ingested, is quantitatively excreted through the alimentary tract.

\section{SUMmary.}

Rats receiving a diet containing aluminium excrete the aluminium entirely by way of the alimentary tract, and there is no clear evidence that any of the aluminium is excreted in the urine.

No definite evidence of absorption of aluminium by the internal organs of such rats has been established.

\section{REFERENCES.}

Flinn and Inouye (1928). J. Amer. Med. Assoc. 80, 1010.

Mackenzie (1930). Biochem. J. 24, 1433.

McCollum, Rask and Becker (1928). J. Biol. Chem. 77, 753.

Myers and Morrison (1928). J. Biol. Chem. 78, 615.

- and Mull (1928). J. Biol. Chem. 78, 605.

Schmidt and Hoagland (1912). J. Biol. Chem. 11, 387.

Wu (1929). Abstracts of Master's theses, Ohio University, 2, 45. 